\title{
The Dimensions of the Citizenship Concept among the Jordanian University Students
}

\author{
Amal M. S. Al-Sabeelah ${ }^{1}$, Fatima E. A. Alraggad ${ }^{1} \&$ Oraib A. Abou-Ameerh ${ }^{1}$ \\ ${ }^{1}$ Department of Psychology and Special Education, Princess Alia College, Al-Balq'a Applied University, \\ Amman, Jordan \\ Correspondence: Oraib A. Abou-Ameerh, Department of Psychology and Special Education, Princess Alia \\ College, Al-Balq'a Applied University, Amman, Jordan. E-mail: oraib_1970@yahoo.com
}

Received: February 24, 2015 Accepted: March 26, 2015 Online Published: July 27, 2015

doi:10.5539/ies.v8n8p87

URL: http://dx.doi.org/10.5539/ies.v8n8p87

\begin{abstract}
This study examined Jordanian university students' knowledge of the citizenship concept while also aiming to reveal whether there were any statistically significant differences in students' knowledge of the citizenship concept due to gender, residence, family income, college, academic level and accumulative grade point average. The study sample comprised 900 B.A level enrolled at six Jordanian universities in the academic year 2012/2013. The research tool was a questionnaire comprising 56 items in four dimensions (identity, loyalty, pluralism, freedom and political participation). Study findings revealed a high level of knowledge of the citizenship concept the total level of the Jordanian university students' in all dimensions was high, despite a medium rating for freedom and political. Results showed statistically significant differences as follows: with regard to the gender variable on the dimensions of identity, pluralism, and freedom and political participation, in favor of males; among rural and urban students on the dimension of loyalty, in favor of rural students; on the dimension of freedom and political participation, in favor of urban students; in favor of high income students on the dimensions of identity, pluralism, freedom and political participation; among students of scientific and humanities colleges on the dimensions of pluralism and freedom and political participation, in favor of humanities colleges; with regard to student academic level on the dimensions of loyalty, pluralism, and freedom and political participation, in favor of the fourth year students. Finally, there were statistically significant differences with regard to the students' accumulative grade point average variable in favor of students with grades of excellent and very good.
\end{abstract}

Keywords: citizenship, identity, political participation

\section{Introduction}

As a result of wide-ranging changes involving the global balance of power and domination of a single super power axis, the appearance of economic and political coalitions, the progress of social structures which foster liberalism and its penetration through geographical and political boarders via communication technology, the focus on the individual's ultimate choices as a reference for daily political life options not only within the work arena but also the civil community and the general domain, it is not surprising that the concept of citizenship should be affected by these winds of change. In addition to the general changes however, the Arabs and the Arabian area are subject to specific changes and have consequently witnessed an obvious transformation in the content, uses, significance, and individual awareness of the principles of citizenship and its related values and behaviors, a transformation which represents a detrimental rather than a constructive tool for the fabric of society and structure of the state (Al-Amer, 2005).

Many societies became concerned by the rapid changes involving most aspects of cultural, social and economic life which consequently affected their constancy and stability and led to the appearance of generally unwelcome trends, values and behavioral patterns. As a result, many states seek to focus on the educational system as one of the most important social systems attempting not only to prepare the individual to face the future, but also to preserve the society's basic principles and values, as well as responding to national hopes and ambitions (Khaled, 2001).

The daily events evidenced in real life situations and illustrated throughout the information media, cultural and political fields reveal a clear progressive challenge for the principle of citizenship and its concepts in general, 
and in the Arab and Islamic world in particular. The factors behind that challenge are numerous, including social, political, cultural and intellectual variables quantified by the framework of a single global power driven by self-interest. This entity, motivated by future interests and intentions, promoted the concept of global citizenship in a new world order known as the age of globalization, sponsoring it for the purpose of becoming the dominating military power (Lee \& Robbins, 1995).

The most important variables considered as basics for the emergence of a new concept of citizenship, called multi-dimensional citizenship, are the following: (Longstreet, 1997)

- Growth of the global communication industry will increase the impact of the English language on people's daily lives.

- Cultural differences will become the focal point for international and national policies.

- Ethical and religious distinctions will increase, markedly affecting centralization of global authority.

- Conflict among groups (ethical, religious, regional) will increase distinctly within and among nations.

- Impact of global media on human behavior will increase noticeably.

- The perception of society and social responsibility will decrease noticeably.

- Religious and racial conflict will increase in many parts of the world, with outbursts of violence and blood-letting.

Citizenship is a group of rights and responsibilities or duties, the rights are the citizen's entitlements from the nation, whereas the responsibilities are the duties that the nation is entitled to expect from the citizen; they are a set of legal obligations through which the citizen's status of belonging in the society is asserted. Although the concepts, rights and duties that compose citizenship may vary from one society to another, they do share specific mutual aspects. Perhaps the most important of these shared values is equality among all citizens in their citizenship rights and duties, facilitating mutual cooperation, strengthening their loyalty to their nation as well as helping them accept each other where there are differences of opinion (Al-Shraideh, 2005).

The concept of national education and citizenship is of vast importance within the social studies field and among the officers of governmental organizations and civil community institutions alike, since it enables citizens to become aware of their rights and duties. National education plays a major role in the process of an individual's upbringing and social responsibility awareness by instilling in them the desired social concepts and values as well as consolidating their place within the society. National education is therefore of significant importance for its vital role in engendering loyalty and a sense of belonging to the nation and the country. (Al-Khouly, 1980)

Citizenship means the individual's geographical belonging to or relation to a certain land, providing that this relation is characterized by continuity, persistence, flexibility, and good relations with others; these provisos are related to a set of abstract and material interests that emerge due to citizen interaction. Thus, we see that the geographical dimension is intermingled with the social dimension regarding the first reality of the citizen. In this respect, Naseef (2000) wrote:"the individual's native country is where he was born and raised, whereas the group's native country is the area where they live and belong to through its belonging to the community itself." Thus, the nation is that which establishes the notion of citizen and consequently citizenship. Given that, true citizenship as a system of rights and duties means the citizen's rights and duties in the state, and the state's rights and duties regarding its citizens because the citizen's rights are duties of the state, and the state's duties are the citizen's duties. Consequently, it is an intimate symbiotic relationship between the two. Hence, we can say that national education is that type of education which is concerned with advancing the national sense, glory and love of country, as well as instilling national loyalty and patriotism in the national group members. It is also that type of education which is conducted on the level of the native country, under the supervision of the national state and including a full range of educational and instructional activities, while interacting with the nation's conditions, needs, heritage, systems and ambitions. In addition, it is the education that involves a number of activities and programs that support national awareness, national commitment and national endeavor. (Naseef, 2000) When discussing citizenship and national education, Al-Debian sees that citizenship is closely related to identity and self-awareness through three dimensions: (Al-Debian, 2006)

First: the mental dimension of citizenship which is the individual's belonging to the native country and to the community within a nation or a state, and the consequent feelings of loyalty and dependence as well as those regarding social relations, mutual commonality and destiny.

Second: the cultural dimension of citizenship which is feeling loyalty to a certain culture and feeling the existence of this culture mentally and rationally, as well as an emotional empathy because it is the place where 
the individual finds his cultural identity; he accepts it and feels satisfied with belonging to it. Following the cultural aspect is the linguistic belonging because when we become a nation without a linguistic projection, we lose the meaning of citizenship on the cultural level and then lose identity and loyalty, in which case citizenship becomes meaningless.

Third: the civil dimension of citizenship which is the individual's duties and rights as a citizen of a state.

Usually, educational institutions from schools to universities play a significant role in instilling national values, attitudes and concepts as well as deepening the spirit of national pride, loyalty and citizens' humanitarian sense. Thus, recognizing the extent of students' comprehension and conception of these values, attitudes and concepts is a clear evidence of true citizenship (Mahaftheh, 2001).

Citizenship is considered one of the issues with political dimensions which express the measure of loyalty and the degree of individuals' participation in protecting and defending the nation. It also expresses the individual's awareness of his rights and duties, his view of others, support for public services and care for the national interest. It also reflects the extent of his realization of his role in confronting the challenges that face both the society and the state (Yaseen, 1998).

The university attempts to offer each student an integrated identity by promoting the spirit of intellectual independence, personal initiative, the feeling of national belonging, and the spirit of social responsibility, in addition to deepening the Islamic faith and its ethical and spiritual values (Al-Ali, 1998). When the student enters the university, he lives a special life that has a distinguished pattern. Through it his strong integrated personality is polished, enabling him to cope with the requirements and developments of his generation. In addition, the university focuses on developing the individual not only on the academic level through the massive amount of information it offers, but also in improving emotional, social and personal aspects through developing different activities to suit the wide range of student attitudes and interests (Al-Zyood \& Aranki, 2003).

If the recent global changes bring new responsibilities and consequences to citizenship, in addition to disarray and shortcomings when structuring Arab awareness and the resultant actions and schisms, and if the development and progress in communication and transmission media in the current age has made possible a new openness, this unfettered accessibility is a double-edged sword. The diverse opinions and attitudes expressed in print lead to confusion and disparity among the youth of both thought and vision in the domain of political concepts, as well as a kind of seizure or brainwashing in the face of oft-repeated and glittering slogans. This is especially pertinent and dangerous because of what is termed in sociology 'the peculiarities of this group culture' which entails being captivated by everything new, the desire for change, self-assertion and independence in a constant struggle against the authority of the older generation's culture. In light of the points mentioned above, the question asked here is "To what extent is the Jordanian university student affected by the recent global changes and their impact on his concept of citizenship dimensions?"

Hahn (1999) stated that the difference between students in the conduct of citizenship is caused by differences in educational systems and practice patterns in the classroom. The results of the study also revealed a variation between the students' political interests.

Mahaftheh (2001) stated that the performance of Irbid Governorate students in the test was the highest, followed by the students of Jerash Governorate and then Tafilah, whereas the last place was occupied by the students of Zarqa and Aqaba. The results of the study revealed also that the students' performance was low in all governorates regarding the economic and environmental aspects, but high regarding the parliamentary aspect. Finally, the findings revealed the existence of statistically significant differences between the males and females for all aspects in favor of males except for the governmental aspect.

In his study, Al-Amer (2005) reported significant differences between males and females in favor of females regarding the dimension of national loyalty; results showed significant differences between college student and university students for all of the study dimensions in favor of the university students; the place of residence variable showed significant differences in favor of urban dwellers; regarding the variable of father's educational status, the differences were in favor of those with a university qualification, and concerning the variable of salary average, the differences were in favor of the highest salary average. However, when looking at the variable of the source of political culture, the differences were between those whose political education was mainly from satellite channels or the Internet, as compared to magazines, books, newspapers, radio, and journals, resulting in favor of those who depend on satellite channels and the Internet for their political education

The results of Al-Subaih (2005) study showed that $80 \%$ of students realize the duties and rights of citizenship, and that $90 \%$ showed a high level of satisfaction with their performance of these duties in general. Also, the 
results indicated the existence of a weakness among the students regarding their political rights represented in the right of election and nomination for elections, and also in their awareness of freedom of expression and expressing opinions, as well as establishing and participating in charity organizations; additionally, discussions rarely took place among the family members regarding any such issues related to the country. However, students generally showed a high degree of citizenship practice especially in their sense of duty towards the country, acknowledging an impact from the family, school and mosque upon learning that part of citizenship which is the citizen's duties towards his country. But it was clear that there was no such connection between the family, school and mosque regarding the citizen's rights.

Yafang (2008) in a research paper found that there was a positive relationship between nurses' job satisfaction and their organizational citizenship behavior, but there was a negative relationship between their job satisfaction and their intention to leave the profession. Also, the results of the study indicated that there was a positive relationship between the nurses' organizational citizenship behavior and their intention to leave the job.

Chughtai (2008) found that job satisfaction had a positive relationship with accomplishing the role and organizational citizenship behavior; the results also revealed the response to organizational commitment was medium within the job satisfaction aspect. Finally, the results revealed that job satisfaction had a stronger impact upon the behavior of organizational citizenship than on the performance of the formal role.

\subsection{Statement of the Problem}

The problem of this study is the identification of the concept of citizenship for the Jordanian university student in light of variables that characterize recent global changes: democracy, human rights, pluralism, political participation, the peace movement, empowerment of women, civil education, sustainable development, globalization, and information and communication technology. Specifically, this study seeks to answer the following questions:

1) What is the extent of Jordanian university students' knowledge of the concept of citizenship?

2) Are there statistically significant differences for the dimensions of citizenship among the Jordanian university students in regard to the variables of gender, residence, father's qualification, mother's qualification, family income, student study level, and the student's accumulative average?

\subsection{Significance of the Study}

This study aims at identifying the concept of citizenship for the Jordanian university student. It is hoped that the results of this study may contribute information that enriches the knowledge available regarding this topic, since citizenship is considered one of the issues with political and security dimensions that express the elements of loyalty and level of individuals' participation in protecting and defending the country, as well as reflecting the citizen's awareness of his role in confronting the challenges that face both the society and the individual. The importance of this study is clarified through revealing the awareness of the Jordanian university student of the dimensions of citizenship, and identifying the statistically significant differences according to the study variables.

\section{Methodology}

\subsection{Participants}

The population of the study included all of the B.A. level students enrolled at six Jordanian universities: three government (Yarmouk, Hashemite, Mu'tah), and three private (Zarqa, Irbid, Petra). These universities were chosen according to the geographical factor, two being located in each of the following three sectors of the country, north, central, and south. However, the sample of the study consisted of 900 male and female students, enrolled in the $2^{\text {nd }}$ semester 2012/2013, 150 students were chosen from the scientific and literary colleges of each of the six universities including $1^{\text {st }}$ and $4^{\text {th }}$ year students, using the intentional method.

\subsection{Instrument}

For the purpose of accomplishing the aim of this study represented as the identification of the concept of citizenship among Jordanian university students, from their own point of view, a questionnaire was developed by the researchers following an extensive review of the related educational literature in addition to a thorough revision of relevant previous studies such as those of Mahaftheh (2001), Al-Amer (2005), Al-Shraideh (2005), Gallup (1977), and Al-Subaih (2005), and utilized in the preparation of the first version of the questionnaire suitable for the Jordanian environment and examined by a group of referees specialized in education, psychology and sociology. In light of their notes on the questionnaire items, some were deleted and others modified so that 
the final version of the questionnaire consisted of 56 items distributed among 4 dimensions: that of identity 12 items, belonging and citizenship 15 items, pluralism and openness to others 18 items, and political freedom and participation 11 items. The researchers used Lickert's quinary scale: very high agreement $=5$ points, high agreement $=4$ points, medium agreement $=3$ points, low agreement $=2$ points, and very low agreement just 1 point.

The instrument was reviewed and validated by a team of 10 specialists in education, psychology and sociology who checked the linguistic accuracy and items for each dimension, implemented the necessary modifications in item content, adding or deleting items as necessary. In light of their notes, some items with a low relevance to the questionnaire domains were replaced after checking their logical validity, resulting in a final total of 56 items distributed among the four dimensions.

Instrument stability using the Test-Retest method was administered to a group of 120 male and female students with an interval time of 2 weeks, with results indicating a consistency coefficient of 0.83 . As an additional test of stability accuracy, the researchers calculated the interior consistency using Cronbach's Alpha which indicated a test stability of 0.94 and considered adequate for the purposes of this study.

To modify the study tool, the researchers divided the degree of agreement into 3 levels: high ( 3.5 and above), medium (2.5-3.49), and low (less than 2.49).

\section{Results and Discussion}

Results of $1^{\text {st }}$ question: What is the extent of Jordanian university student's knowledge of the concept of citizenship?

To answer this question, means and standard deviations were calculated for the dimensions of the concept of citizenship, as seen in Table 1 .

First: the dimension of identity

Table 1 clarifies the means and standard deviations for the items of identity ordered according to their level.

Table 1. Means \& SDs for the dimension of identity arranged according to level

\begin{tabular}{lllll}
\hline No. & Item & Mean & SD & Level \\
\hline 1 & Media openness leads to spreading the current ideas. & 4.34 & 1.30 & High \\
2 & Openness to the world makes the society lose its identity. & 4.40 & 0.96 & High \\
3 & Information technology leads to changes in the youth's political education. & 4.40 & 0.93 & High \\
4 & Islamic religious heritage includes solutions for all of our current problems. & 4.33 & 1.07 & High \\
5 & I don't accept any discussion related to issues of religious faith. & 4.26 & 1.28 & High \\
6 & The individual's loyalty should be directed towards his society. & 4.18 & 1.11 & High \\
7 & Considering power according to the laws of modernity is a requirement for & 4.12 & 1.13 & High \\
& advancement. & & & \\
8 & The current media revolution represents a mess and pollution of the youth's & 3.85 & 1.42 & High \\
9 & political concepts. & 3.60 & 1.24 & High \\
10 & If a political book publishes something unfamiliar, I will not read it. & 3.46 & 1.36 & Medium \\
11 & Most of the Western political views are destructive and don't suit our society. & 3.20 & 1.40 & Medium \\
12 & I feel nervous of those who demand change in politics. & 3.10 & 1.31 & Medium \\
\hline Total & & 4.25 & 1.30 & High \\
\hline
\end{tabular}

It is clear in Table 1 that the total mean for the questionnaire items for the dimension of identity was 4.25 , with a standard deviation of 1.30 which indicates that the overall degree for the Jordanian university students' knowledge of citizenship for the dimension of identity was high. That indicates a cultural awareness by the Jordanian university student regarding the dimension of identity as one of the citizenship dimensions reflecting the cultural and educational level of the Jordanian society and consequently reflecting on the students' perception 
of their national identity, so this dimension achieved a high level.

Results of the items in this dimension: the item (Media openness leads to spreading the current ideas) achieved $1^{\text {st }}$ place with a mean of 4.43 and a standard deviation of 1.30 , whereas the item (Openness to the world makes the society lose its identity) gained $2^{\text {nd }}$ rank with a mean of 4.40 and a standard deviation of 0.96 . The item (Information technology leads to changes in the youths' political education) came third with a mean of 4.40 and a standard deviation of 0.93 . The rank before the final was occupied by the item (Most Western political views are destructive and don't suit our society) with a mean of 3.20 and a standard deviation of 1.31, while the last rank was given to (I feel nervous of those who demand change in politics) with a mean of 3.10 and a standard deviation of 1.30 .

This result is due to the important role of the family, school and university, since the openness of the Jordanian society to the whole world and the use of mass media have influenced the individual's general awareness and that of the university community particularly, where the student became aware of the negative notions and realized the positive ideas of openness and its risks to individuals. Consequently, that reflected upon their identity so they benefit positively from this openness while avoiding the negative effects on their identity and citizenship in general.

Second: the dimension of belonging \& citizenship

Table 2 clarifies the means and standard deviations for the dimension of belonging and citizenship, ordered according to level.

Table 2. Means \& SDs for the dimension of belonging \& citizenship arranged according to level

\begin{tabular}{|c|c|c|c|c|}
\hline No. & Item & Mean & $\mathrm{SD}$ & Level \\
\hline 1 & $\begin{array}{l}\text { I think violence and extremism threaten the country's interest and stability, and } \\
\text { offend Islam. }\end{array}$ & 4.75 & 0.89 & High \\
\hline 2 & Each individual should do his best for the sake of his country. & 4.70 & 0.95 & High \\
\hline 3 & Citizenship is the individual's responsibility to take part in public affairs. & 4.60 & 0.92 & High \\
\hline 4 & Stability and feeling secure and safe is necessary for hard work. & 4.40 & 1.18 & High \\
\hline 5 & The individual's loyalty should be directed towards his society. & 4.35 & 1.02 & High \\
\hline 6 & Nations can achieve a lot if their individuals have a sense of responsibility. & 4.20 & 1.15 & High \\
\hline 7 & $\begin{array}{l}\text { Amongst my most important life principles is achieving a high level of } \\
\text { performance and contribution to the country. }\end{array}$ & 4.12 & 1.17 & High \\
\hline 8 & $\begin{array}{l}\text { I believe in the necessity of granting women their political rights in the Arab } \\
\text { communities. }\end{array}$ & 4.00 & 1.22 & High \\
\hline 9 & $\begin{array}{l}\text { In light of what satellite channels broadcast, my conviction in the national } \\
\text { political approach increases. }\end{array}$ & 3.85 & 1.10 & High \\
\hline 10 & In light of globalization, national unity is considered an incredible feeling. & 3.70 & 1.26 & High \\
\hline 11 & Mediation is one of the most important means for achieving interests. & 3.41 & 1.50 & Medium \\
\hline 12 & Future evokes lots of worries for the youth. & 3.35 & 1.46 & Medium \\
\hline 13 & Life and current circumstances decreased the feeling of loyalty to the nation. & 3.02 & 1.66 & Medium \\
\hline 14 & $\begin{array}{l}\text { Increasing loyalty to the nation means fanaticism, and it conflicts with the idea } \\
\text { of global agreement. }\end{array}$ & 2.90 & 1.85 & Medium \\
\hline 15 & $\begin{array}{l}\text { In light of the unstable global conditions, I don't feel the importance of what is } \\
\text { called security or safety. }\end{array}$ & 2.75 & 1.96 & Medium \\
\hline Total & & 3.78 & 1.06 & High \\
\hline
\end{tabular}

It is clear in Table 2 that the overall mean for the questionnaire items for the dimension of belonging and citizenship was 3.87 , with a standard deviation of 1.06 which indicates that the overall degree for the Jordanian university students' knowledge of citizenship for the dimension of belonging and citizenship was high. That indicates that the Jordanian university student realizes the importance of an individual's being true to himself, 
and consequently reflects on the belonging to the family and society, strengthening his belonging and citizenship.

Regarding the results of items in this dimension, the item (I think violence and extremism threaten the country's interest and stability, and offend Islam) achieved 1st place with a mean of 4.75 and a standard deviation of 0.89 , whereas the item (Each individual should do his best for the sake of his country) was given 2nd rank with a mean of 4.70 and a standard deviation of 0.95 . The item (Citizenship is the individual's responsibility to take part in public affairs) came third with a mean of 4.60 and a standard deviation of 0.92 . The rank before the final was occupied by the item (Increasing loyalty to the nation means fanaticism, and it contradicts the idea of global agreement) with a mean of 2.90 and a standard deviation of 1.85 , and the last rank was given to (In light of the unstable global conditions, I don't feel the importance of what is called security or safety) with a mean of 2.75 and a standard deviation of 1.96 .

The explanation of this result could be the state of cultural awareness of the Jordanian society, particularly on the university campuses, which affects the individuals' notion of belonging and citizenship. Thus, the individual's self-interest arises from the general interest, and consequently the individual's interest in country is linked to his private interests since the individual and the country are one integral body. Hence, the individual seeks to perform his roles for the sake of the nation, and others performance of their roles leads to integration of these roles and ultimately, united national interest. So, the individual's performance of his different roles is a clear indicator for belonging and citizenship.

Third: the dimension of pluralism \& openness to others

Table 3 clarifies the means and standard deviations for the dimension of pluralism and openness to others arranged according to level.

Table 3. Means \& SDs for the dimension of pluralism \& openness to others arranged according to level

\begin{tabular}{|c|c|c|c|c|}
\hline No. & Item & Mean & SD & Level \\
\hline 1 & $\begin{array}{l}\text { Having multi parties in developing countries is a political risk that must be } \\
\text { abandoned. }\end{array}$ & 4.70 & 0.96 & High \\
\hline 2 & $\begin{array}{l}\text { There must be wide control over what is published for the general public. Not } \\
\text { every opinion is valid for publishing. }\end{array}$ & 4.50 & 1.33 & High \\
\hline 3 & $\begin{array}{l}\text { Reforming and improving a society can only be achieved through its isolation } \\
\text { and exploitation of its own human and material resources. }\end{array}$ & 4.21 & 1.18 & High \\
\hline 4 & $\begin{array}{l}\text { The characteristics of the current age demand understanding and activating } \\
\text { various political ideologies. }\end{array}$ & 4.20 & 1.13 & High \\
\hline 5 & Information and cultural openness increase the youth's political awareness. & 4.16 & 1.31 & High \\
\hline 6 & Satellite channels lead to confusion in the youth's ideas. & 4.16 & 1.11 & High \\
\hline 7 & All ideas and opinions may be discussed and criticized & 4.03 & 1.26 & High \\
\hline 8 & $\begin{array}{l}\text { The Western democratic political system is the most successful system for } \\
\text { leadership (of the public) }\end{array}$ & 4.03 & 1.47 & High \\
\hline 9 & Media openness leads to the spread of current ideas. & 4.01 & 1.03 & High \\
\hline 10 & $\begin{array}{l}\text { Global communication industry increases the importance of the English } \\
\text { language in daily life. }\end{array}$ & 3.90 & 1.21 & High \\
\hline 11 & It is useless to argue with opposing people because their ideas are wrong. & 3.65 & 1.26 & High \\
\hline 12 & Civilization conflict obliges us to resist all incoming ideas & 3.55 & 1.08 & High \\
\hline 13 & Democratic values can obsorb all differences affecting the society's stability. & 3.46 & 1.32 & Medium \\
\hline 14 & The one-party system is the best for achieving the society's interests. & 3.35 & 1.46 & Medium \\
\hline 15 & $\begin{array}{l}\text { The spread of Western values and ideas leads to the spread of corruption in our } \\
\text { country. }\end{array}$ & 3.25 & 1.45 & Medium \\
\hline 16 & Many youth are deceived by incorrect and directed (prompted)concepts. & 3.01 & 1.31 & Medium \\
\hline 17 & $\begin{array}{l}\text { One of the features of the civilized person is accepting the political thoughts of } \\
\text { developed countries. }\end{array}$ & 2.99 & 1.44 & Medium \\
\hline
\end{tabular}




\begin{tabular}{lllll}
\hline $18 \quad$ We must adopt everything Western because they are more developed. & 2.50 & 1.64 & Medium \\
\hline Total & 3.75 & 1.16 & High \\
\hline
\end{tabular}

As illustrated in Table 3, the overall mean for the dimension of pluralism and openness to others was 3.75 with a standard deviation of 1.16, indicating a high overall level of knowledge in this dimension. This result illustrates a high general awareness in the Jordanian society and especially among the university student community, of the need for openness to the outside world and the importance of considering diverse ideas and innovations that can benefit the national interest.

Results regarding the items in this dimension: (Having multi parties in developing countries is a political risk that must be abandoned) ranked $1^{\text {st }}$ with a mean of 4.70 and a standard deviation of 0.96 , whereas the item (There must be a wide control for what is published regarding people, not every opinion can be published) was given $2^{\text {nd }}$ rank with a mean of 4.50 and a standard deviation of 1.33 . The item (Reforming and improving any society could be through being secluded and exploiting its human and material resources) ranked $3^{\text {rd }}$ with a mean of 4.21 and a standard deviation of 1.18. The item before the last (One of the features of the civilized person is accepting the political thoughts of developed countries) ranked $4^{\text {th }}$ with a mean of 2.99 and a standard variation of 1.44, while the lowest rank was given to (We must take every thing from the West because they are more developed) with a mean of 2.5 and a standard deviation of 1.64 .

This result could be ascribed to reflecting different aspects of the society's culture in individuals' awareness of the importance of openness to the outside world and benefiting from development regarding the aspects that support the country's interest, providing that positive attributes are accepted and consolidated, while negative influences are rejected. Accepting and achieving the necessity for selectivity and discretion is an indication of the high level of awareness and recognition of the means by which the country can develop without harming its various material and abstract qualities. Hence, the study sample members believe in the necessity of promoting pluralism and increasing the range of ideas for general interest and discussion. This can only be achieved through multi-party diversity which is an advantage to the national interest from every point of view in combating selfishness, individualism and self-interest. On the other hand, we can see that the university students reject negative influences which are against the national interest, as evidenced by the results of the last item (We should adopt everything Western because ......) an indicator of their awareness that everything from the West is neither suitable or desirable, whether from the personal, individual, societal or cultural point of view, nor in the general national interest.

Fourth: the dimension of freedom \& political participation

Table 4 clarifies the means and standard deviations for the dimension of freedom and political participation arranged according to level.

Table 4. Means \& SDs for the dimension of pluralism \& openness to others arranged according to level

\begin{tabular}{lllll}
\hline No. & Item & Mean & SD & Level \\
\hline 1 & $\begin{array}{l}\text { I think freedom of expression has limits that should not be exceeded in order to } \\
\text { prevent the spread of chaos. }\end{array}$ & 4.20 & 1.13 & High \\
2 & $\begin{array}{l}\text { It is necessary to activate control mechanisms on all that is broadcasted so as to } \\
\text { preserve the country's currently prevalent political system. }\end{array}$ & 4.01 & 1.16 & High \\
3 & $\begin{array}{l}\text { In my opinion, success and failure are equal these days, so being giving and } \\
\text { hard working is of no importance }\end{array}$ & 3.90 & 1.27 & High \\
4 & $\begin{array}{l}\text { It is necessary to offer individuals full opportunity to express their opinions } \\
\text { freely. }\end{array}$ & 3.75 & 1.41 & High \\
5 & $\begin{array}{l}\text { Personally, I believe that political decision-making is a difficult and crucial } \\
\text { issue, so not everyone has the ability to participate in it. }\end{array}$ & 3.70 & 1.34 & High \\
6 & $\begin{array}{l}\text { It is preferable for people not to become involved in political life since it is the } \\
\text { responsibility of the government and rulers only. }\end{array}$ & 3.45 & 1.32 & Medium \\
7 & I prefer to be a normal person since it is not worth caring about life & 3.31 & 1.51 & Medium \\
\hline
\end{tabular}




\begin{tabular}{llrlr}
8 & $\begin{array}{l}\text { In order to achieve targeted development, it is necessary to change many } \\
\text { political views. }\end{array}$ & 3.25 & 1.46 & Medium \\
$9 \quad \begin{array}{l}\text { Participating in carrying responsibility exposes people to problems they could } \\
\text { do without }\end{array}$ & 2.98 & 1.55 & Medium \\
$10 \quad \begin{array}{l}\text { It is acceptable for mankind to sometimes resort to violence and use of force to } \\
\text { achieve goals. }\end{array}$ & 2.95 & 1.61 & Medium \\
$11 \quad$ I think that the use of power and violence may be necessary in some situations & 2.85 & 1.53 & Medium \\
\hline The general average & 3.48 & 1.29 & Medium \\
\hline
\end{tabular}

As shown in Table 4, the overall mean of the questionnaire items for the dimension 'freedom and political participation' was 3.48 with a standard deviation of 1.29 , indicating a medium level. This result reflects the students' general attitude at this age as being mainly directed towards building their future in the academic field, accompanied only by moderate political participation that will not affect their future.

Results of this dimension: the item (I think freedom of expression has limits that should not be exceeded to prevent the spread of chaos) achieved 1st rank with a mean of 4.20 and a standard variation of 1.13 , whereas the item (It is necessary to activate control mechanisms on all that is broadcasted so as to preserve the country's currently prevalent political system.) ranked 2nd with a mean of 4.01 and a standard deviation of 1.16. The item (In my opinion, success and failure are equal these days, so being giving and hardworking is of no importance) ranked 3rd with a mean of 3.90 and a standard variation of 1.27. The 4th rank was occupied by the item (An individual may sometimes be justified in using power and violence to achieve his goals) with a mean of 2.95 and a standard variation of 1.61, and the lowest rank was given to (I think the use of violence and power may be necessary in some circumstances) with a mean of 2.85 and a standard variation of 1.53.

These results illustrate the degree to which the university students' awareness of the concept of citizenship is reflected by the different dimensions. Clearly, their first priority is to build their future by graduating from university, and that is their first step towards freedom, reflected in freedom of expression and their concept of success and failure. When the student becomes more aware of the importance of this stage he is experiencing, it is reflected upon all aspects of his life. Hence, the student tries to be up-to-date with developments in the world and life around him, without affecting his future in any way. He has set himself a standard of progress, taking the first steps towards freedom by preparing and qualifying himself. On the other hand, we can see the reflection of students' cultural awareness through their refusal of violence, power and fanaticism in order to achieve goals, this being clearly illustrated by these items receiving by far the lowest rating.

Results of 2nd question: Are there statistically significant differences for the dimensions of citizenship among the Jordanian university students in regard to the variables of gender, residence, father's qualification, mother's qualification, family income, student's studying level, and the student's accumulative average?.

To answer this question, it was divided into the following sub-questions:

1) Are there statistically significant differences for the dimensions of citizenship among the Jordanian university students in regard to the variable of gender?

To answer this question, means, standard deviations and (t-test) were calculated as seen in Table 5.

Table 5. Means, SDs, (t-test) values \& significance level for citizenship dimensions according to gender

\begin{tabular}{|c|c|c|c|c|c|c|c|}
\hline \multirow{3}{*}{ No. } & \multirow{3}{*}{ Dimension } & \multicolumn{4}{|c|}{ Gender } & \multirow{3}{*}{ t- value } & \multirow{3}{*}{ Significance level } \\
\hline & & \multicolumn{2}{|c|}{ Males } & \multicolumn{2}{|c|}{ Females } & & \\
\hline & & Mean & SD & Mean & SD & & \\
\hline 1 & Identity & 4.01 & 1.13 & 3.86 & 1.23 & 0.17 & $* 0.04$ \\
\hline 2 & Belonging \& citizenship & 4.25 & 1.06 & 4.19 & 1.12 & 0.06 & 0.26 \\
\hline 3 & Pluralism \& accepting others & 4.10 & 0.98 & 3.89 & 1.31 & 0.21 & $* 0.01$ \\
\hline 4 & Freedom \& political participation & 4.52 & 1.36 & 4.35 & 1.29 & 0.17 & $* 0.03$ \\
\hline
\end{tabular}

*SSD $=\alpha \leq 0.05$. 
Table 5 demonstrates the following:

- Existence of statistically significant differences between the male and female students regarding the dimensions of citizenship (identify, pluralism, accepting others, freedom, and political participation) in favor of male students.

- $\quad$ No existence of statistically significant differences for the dimension (belonging \& citizenship) between the male and female students.

The researchers ascribe the existence of differences in favor of male students regarding the dimensions of (identify, pluralism, accepting others, freedom, and political participation) to a reflection of family background and education, since the nature of the Jordanian society is a masculine one where the focus of education is on males rather than females, especially in political issues. The structure of the Jordanian society entails more participation from males where females' participation is only restricted to issues related to them particularly, although women in Jordan have become more integrated in all sectors and levels, so that it is possible for a woman to become a minister, business manager, or even company president. Also, no differences were shown between the male and female students regarding the dimension of belonging and citizenship.

2) Are there statistically significant differences for the dimensions of citizenship among the Jordanian university students in regard to the variable of residence?

To answer this question, means, standard deviations and (t-test) were calculated as seen in Table 6 .

Table 6. Means, SDs, (t-test) values \& significance level for citizenship dimensions according to residence

\begin{tabular}{|c|c|c|c|c|c|c|c|}
\hline \multirow{3}{*}{ No. } & \multirow{3}{*}{ Dimension } & \multicolumn{4}{|c|}{ Residence } & \multirow{3}{*}{ t- value } & \multirow{3}{*}{ Significance level } \\
\hline & & \multicolumn{2}{|c|}{ Males } & \multicolumn{2}{|c|}{ Females } & & \\
\hline & & Mean & SD & Mean & SD & & \\
\hline 1 & Identity & 3.36 & 1.16 & 4.50 & 1.41 & -0.16 & 0.41 \\
\hline 2 & Belonging \& citizenship & 4.45 & 1.01 & 4.23 & 1.17 & 0.22 & $* 0.04$ \\
\hline 3 & Pluralism \& accepting others & 4.16 & 0.95 & 4.11 & 0.92 & -0.03 & 0.36 \\
\hline 4 & Freedom \& political participation & 4.01 & 1.42 & 4.15 & 1.04 & -0.17 & $* 0.02$ \\
\hline
\end{tabular}

$* \operatorname{SSD}=\alpha \leq 0.05$.

Table 6 demonstrates the following:

- Existence of statistically significant differences between the students living in villages and those in cities regarding the dimensions of (belonging \& citizenship, freedom \& political participation), in favor of students who live in villages for (belonging \& citizenship) and in favor of students who live in cities for (freedom \& political participation).

- There were no statistically significant differences for the other dimensions (identity \& pluralism \& accepting others) between the students living in villages and cities.

The researchers ascribe the existence of differences in favor of students living in villages regarding the dimensions of (belonging \& citizenship) as the reflection of family education which focuses on the individual's belonging to his family which in turns adds to the national interest. Hence, when the individual belongs to his family and his community, this belonging extends to the larger society which is his country. Regarding the existence of differences for the benefit of students living in cities for the dimensions of (freedom \& political participation), although there is no difference between the city residents and village residents in ambitions and interests, what is evident in the responses of the city residents is more regarding openness and exposure, consequently the margin of freedom for the city resident is wider than for the village resident, who is usually more attached to his family recommendations which usually hinder their children's participation in political issues. Thus, the differences were for the benefit of students living in cities for the dimensions of freedom and political participation.

3) Are there statistically significant differences for the dimensions of citizenship among the Jordanian university students in regard to the variable of family income?

To answer this question, means \& ANOVA were calculated as seen in Table 7. 
Table 7. Means, one-way ANOVA according to family income

\begin{tabular}{|c|c|c|c|c|c|}
\hline \multirow{3}{*}{ Dimension } & \multicolumn{3}{|c|}{ Family income } & \multirow{3}{*}{ f-value } & \multirow{3}{*}{$\begin{array}{l}\text { Significance } \\
\text { level }\end{array}$} \\
\hline & $\begin{array}{l}\text { Less than JD } \\
250\end{array}$ & $250-500$ & $\begin{array}{l}\text { More than JD } \\
500\end{array}$ & & \\
\hline & Mean & Mean & Mean & & \\
\hline Identity & 3.92 & 3.97 & 4.01 & 1.85 & $* 0.02$ \\
\hline Belonging \& citizenship & 4.09 & 4.16 & 4.12 & 2.18 & 0.45 \\
\hline Pluralism \& accepting others & 3.88 & 4.08 & 4.11 & 2.26 & $* 0.04$ \\
\hline $\begin{array}{l}\text { Freedom } \\
\text { participation }\end{array}$ & 3.94 & 4.17 & 4.36 & 2.07 & $* 0.01$ \\
\hline
\end{tabular}

$* \mathrm{SSD}=\alpha \leq 0.05$.

Table 7 demonstrates the following:

- Existence of statistically significant differences between students regarding the variable of family income in the dimensions (identity, pluralism, accepting others, freedom \& political participation).

- No existence of statistically significant differences for the dimensions (belonging \& citizenship) where the calculated f-value was 2.18 and the significance level was 0.184 . To reveal the location of these statistically significant differences between the means of the dimensions of citizenship among the students in accordance to the variable of family income, the researchers used Scheffe test to locate the source of these differences in the average of family income as seen in Table 8 .

Table 8 . Scheffe test for locating the source of differences according to family income

\begin{tabular}{|c|c|c|c|c|c|}
\hline Dimension & Family income & Mean & $\begin{array}{lll}\text { Less } & \text { than } \text { JD } \\
250 & & \end{array}$ & $250-500$ & $\begin{array}{l}\text { More than JD } \\
500\end{array}$ \\
\hline \multirow{3}{*}{ Identity } & Less than JD 250 & 3.92 & & & \\
\hline & $250-500$ & 3.97 & & & \\
\hline & $\begin{array}{l}\text { More than JD } \\
500\end{array}$ & 4.01 & $*$ & $*$ & \\
\hline \multirow{3}{*}{ Pluralism \& accepting others } & Less than JD 250 & 3.88 & & & \\
\hline & $250-500$ & 4.08 & & & \\
\hline & $\begin{array}{l}\text { More than JD } \\
500\end{array}$ & 4.12 & $*$ & $*$ & \\
\hline \multirow{3}{*}{$\begin{array}{l}\text { Freedom } \\
\text { participation }\end{array}$} & Less than JD 250 & 3.94 & & & \\
\hline & $250-500$ & 4.17 & & & \\
\hline & $\begin{array}{l}\text { More than JD } \\
500\end{array}$ & 4.36 & $*$ & $*$ & \\
\hline
\end{tabular}

$* \mathrm{SSD}=\alpha \leq 0.05$.

Table 8 which is related to the Scheffe test for locating the source of differences according to the variable of family income clearly shows statistically significant differences ascribed to the variable of family income in favor of students whose family income is high (more than JD 500), in all 6 differences.

The researcher ascribes this result to the fact that high income families try to offer their children a social status through their financial situation, and consequently they seek more freedom specially economic and political, consequently demanding that they constantly have a role in the political decisions which in turn affect their income level. As a result, these families see that their children's identity can be formed through the high financial position, state, ensuring them of a position in that social class. 
4) Are there statistically significant differences for the dimensions of citizenship among the Jordanian university students in regard to the college variable?

To answer this question, means, standard deviations and (t-test) were calculated as seen in Table 9.

Table 9. Means, SDs, (t-test) values \& significance level for citizenship dimensions according to college

\begin{tabular}{llcccccc}
\hline \multirow{2}{*}{ No. Dimension } & \multicolumn{5}{c}{ College } & \multirow{2}{*}{ S } & \multicolumn{3}{c}{ Sumanitarian } & \multicolumn{2}{c}{ Scientific } & t- value & Significance level \\
\cline { 3 - 6 } & & Mean & SD & Mean & SD & & \\
\cline { 2 - 6 } & Identity & 4.52 & 1.98 & 4.62 & 1.22 & -0.10 & 0.22 \\
2 & Belonging \& citizenship & 4.33 & 1.07 & 4.48 & 1.04 & -0.15 & 0.31 \\
3 & Pluralism \& accepting others & 4.16 & 1.12 & 4.11 & 1.08 & 0.05 & $* 0.01$ \\
4 & Freedom \& political participation & 4.08 & 0.96 & 4.01 & 0.97 & 0.07 & $* 0.03$ \\
\hline
\end{tabular}

$* \mathrm{SSD}=\alpha \leq 0.05$.

Table 9 demonstrates the following:

- Existence of statistically significant differences between students regarding the variable of college (humanitarian or scientific) in the dimensions (pluralism, accepting others, freedom \& political participation) in favor of humanitarian college students.

- $\quad$ No existence of statistically significant differences for the dimensions (identity, belonging \& citizenship) between the students of humanitarian and scientific colleges.

The researchers ascribe the existence of differences in favor of students of humanitarian colleges regarding the dimensions of (pluralism, accepting others, freedom \& political participation) to differences in the nature of study required of students of scientific and humanitarian colleges, in that the level of study demanded of scientific college students is higher and demands constant commitment and dedication, including continuous follow-up with the professor in his office, hours spent in applied or practical work in laboratories, as well as staying up-to-date with references in the library. The humanitarian college students however, have more time and opportunity to participate in student clubs, assemblies and activities. In addition, they have more opportunity for contact with their colleagues who may belong to political parties, which is reflected in the students' view of political participation outside university. Consequently, that attitude is reflected on these students' belief in pluralism, accepting others, freedom and political participation either on campus or outside the university.

5) Are there statistically significant differences for the dimensions of citizenship among the Jordanian university students in regard to the variable of studying level?

To answer this question, means, standard deviations and (t-test) were calculated as seen in Table 10.

Table 10. Means, SDs, (t-test) values \& significance level for citizenship dimensions according to studying level

\begin{tabular}{|c|c|c|c|c|c|c|c|}
\hline \multirow{3}{*}{ No. } & \multirow{3}{*}{ Dimension } & \multicolumn{4}{|c|}{ Study level } & \multirow{3}{*}{ t- value } & \multirow{3}{*}{ Significance level } \\
\hline & & \multicolumn{2}{|c|}{$1^{\text {st }}$ year } & \multicolumn{2}{|c|}{$4^{\text {th }}$ year } & & \\
\hline & & Mean & SD & Mean & SD & & \\
\hline 1 & Identity & 4.16 & 0.96 & 3.61 & 0.94 & 0.55 & $* 0.01$ \\
\hline 2 & Belonging \& citizenship & 3.98 & 1.39 & 4.24 & 1.56 & -0.26 & $* 0.01$ \\
\hline 3 & Pluralism \& accepting others & 3.29 & 0.89 & 4.35 & 1.17 & -0.43 & $* 0.03$ \\
\hline 4 & Freedom \& political participation & 4.01 & 0.98 & 4.17 & 0.86 & -0.16 & $* 0.02$ \\
\hline
\end{tabular}

$* \mathrm{SSD}=\alpha \leq 0.05$. 
Table 10 demonstrates the following:

- Existence of statistically significant differences between students regarding the variable of studying level/year (first or fourth) in all dimensions (identity, belonging \& citizenship, pluralism \& accepting others, freedom $\&$ political participation) in favor of $4^{\text {th }}$ year students.

Researchers ascribe the existence of differences between the 1st and 4th year students regarding the dimensions of (identity, belonging \& citizenship, pluralism \& accepting others, political participation) in favor of 4th year students, to the nature of university life and all its positive advantages. In addition to academic learning through lectures and study, these four years on campus provide life experience through contact with colleagues, students from various backgrounds, and also university employees, all of which contributes to the high level of recognition of the importance of these dimensions, whereas the 1st year students have had little experience of that life, so the more mature and better informed responses and attitudes of the 4th year students come as no surprise.

6) Are there statistically significant differences for the dimensions of citizenship among the Jordanian university students in regard to the variable of student's accumulative average?

To answer this question, means and One-way ANOVA were calculated as seen in Table 11.

Table 11. Means \& one-way ANOVA according to the student's accumulative average

\begin{tabular}{|c|c|c|c|c|c|c|c|}
\hline \multirow{3}{*}{ Dimension } & \multicolumn{5}{|c|}{ Students' accumulative average } & \multirow{3}{*}{ f-value } & \multirow{3}{*}{$\begin{array}{c}\text { Significance } \\
\text { level }\end{array}$} \\
\hline & $\begin{array}{c}\text { Under } \\
\text { observation }\end{array}$ & Accepted & Good & $\begin{array}{l}\text { Very } \\
\text { good }\end{array}$ & Excellent & & \\
\hline & Mean & Mean & Mean & Mean & Mean & & \\
\hline Identity & 2.65 & 2.90 & 3.16 & 4.20 & 4.53 & 1.86 & $* 0.03$ \\
\hline $\begin{array}{c}\text { Belonging \& } \\
\text { citizenship }\end{array}$ & 4.27 & 3.96 & 4.08 & 4.39 & 4.48 & 1.98 & $* 0.01$ \\
\hline $\begin{array}{c}\text { Pluralism \& accepting } \\
\text { others }\end{array}$ & 3.78 & 3.64 & 3.98 & 4.26 & 4.42 & 2.26 & $* 0.01$ \\
\hline $\begin{array}{l}\text { Freedom \& political } \\
\text { participation }\end{array}$ & 2.85 & 3.52 & 4.16 & 4.45 & 4.56 & 2.07 & $* 0.01$ \\
\hline
\end{tabular}

Table 11 demonstrates the following:

- Existence of statistically significant differences between students regarding the variable of students' average for all citizenship dimensions (identity, belonging \& citizenship, pluralism \& accepting others, freedom \& political participation) and to reveal the source of these statistically significant differences between the means for the dimensions of citizenship among students in accordance to the variable of accumulative average, the researcher used Scheffe test to locate these sources, as clarified in Table 12.

Table 12. Scheffe test for locating the source of differences according to average

\begin{tabular}{cccccccc}
\hline Dimension & $\begin{array}{c}\text { Students' } \\
\text { average }\end{array}$ & Mean & $\begin{array}{c}\text { Under } \\
\text { observation }\end{array}$ & Accepted & Good & $\begin{array}{c}\text { Very } \\
\text { good }\end{array}$ & Excellent \\
\hline \multirow{6}{*}{ Identity } & Under & 2.65 & & & & & \\
& observation & Accepted & 2.90 & & & & \\
& Good & 3.16 & & & & \\
& Very good & 4.20 & $*$ & $*$ & $*$ & \\
& Excellent & 4.53 & $*$ & $*$ & $*$ & $*$ \\
\hline
\end{tabular}




\begin{tabular}{|c|c|c|c|c|c|c|}
\hline \multirow{5}{*}{ Belonging \& citizenship } & $\begin{array}{c}\text { Under } \\
\text { observation }\end{array}$ & 4.27 & & & & \\
\hline & Accepted & 3.96 & & & & \\
\hline & Good & 4.08 & & & & \\
\hline & Very good & 4.39 & $*$ & $*$ & & \\
\hline & Excellent & 4.48 & $*$ & $*$ & $*$ & $*$ \\
\hline \multirow{5}{*}{$\begin{array}{c}\text { Pluralism \& accepting } \\
\text { others }\end{array}$} & $\begin{array}{c}\text { Under } \\
\text { observation }\end{array}$ & 3.78 & & & & \\
\hline & Accepted & 3.64 & & & & \\
\hline & Good & 3.98 & & & & \\
\hline & Very good & 4.26 & $*$ & $*$ & & \\
\hline & Excellent & 4.42 & $*$ & $*$ & $*$ & $*$ \\
\hline \multirow{5}{*}{$\begin{array}{l}\text { Freedom \& political } \\
\text { participation }\end{array}$} & $\begin{array}{c}\text { Under } \\
\text { observation }\end{array}$ & 2.85 & & & & \\
\hline & Accepted & 3.52 & & & & \\
\hline & Good & 4.16 & & & & \\
\hline & Very good & 4.45 & $*$ & $*$ & $*$ & \\
\hline & Excellent & 4.56 & * & * & * & * \\
\hline
\end{tabular}

$* \mathrm{SSD}=\alpha \leq 0.05$.

Table 12 results of the Scheffe test for locating the difference source according to the variable of students' accumulative average, clearly showing:

- The existence of statistically significant differences ascribed to the variable of accumulative average, these differences being in favor of students whose averages were high (excellent \& very good).

The researcher sees the high accumulative average is an indicator for the quality of the student. Thus, the student who is academically distinguished and has a high average realizes the fact of having an independent personality and his own identity, represented in doing what is required of him at this age which is achievement in his studies. Since he has self-confidence and self-esteem, this will be reflected on his sense of belonging and nationalism. He also believes in the importance of pluralism and recognition of others' ideas, taking what is beneficial for the sake of the country's interest. Besides, he believes in freedom and political participation since more awareness and contact with others reinforces self-confidence. Whenever the person has more self-confidence, his excellence, awareness and recognition increase, and that leads to success and excellence which in turn adds to the country's interest.

\section{Recommendations}

In light of the study results, the researchers recommend the following points:

- The necessity of including concepts of citizenship within all curricula especially since the basis of citizenship, its duties and rights are derived from our true religion (Islam).

- Allocating an independent studying curriculum for citizenship education, including the principles of democracy, pluralism and political participation.

- Focusing on revealing the principle of citizenship within our social atmosphere by extending the areas of participation in public affairs.

- Replacing the culture of silence and lecturing in instruction with the dialogue style which helps the student build self-confidence, and that depends on freedom of opinion. It also asserts constructive dialogue, discussion, positive criticism between students and professors and administrators. 


\section{References}

Al-Ali, S. (1998). Some Factors Affecting King Saud University Students' Participation in Students' Activities (Unpublished M.A. dissertation). College of Education, King Saud University, Riyadh.

Al-Amer, O. (1999). Citizenship in the Recent Western Thought, A Critical Study from an Islamic Perspective. Al-Ebikan Library, Riyadh.

Al-Amer, O. (2005). The Impact of Cultural Openness on The Saudi Youth's Self-concept. The 13th Conference for the Educational Work Leaders, Al-Baha, Saudi Arabia

Al-Debian, A. B. M. (2006). The Speech of The General Manager of The Islamic Centre in London in the Seminar (The Experiences \& Issues of Education on Citizenship) in the book "Studies \& Researches of the Third Arab Meeting for Teaching and Sustainable Education in the Arab World". Beirut, Lebanon.

Al-Khouli, M. A. (1980). Education Dictionary, Dar Al-Elm for Millions. Beirut, Lebanon.

Al-Quseibi, G. (2002). Globalization \& National Identity. Al-Ebikan Library, Riyadh, Saudi Arabia.

Al-Shraideh, K. (2005). Making Citizenship in a Changing World: A Vision in Social Policy. The 13th Conference for the Educational Work Leaders, Al-Baha, Saudi Arabia

Al-Subaih, A. (2005). Citizenship As Perceived by the Secondary Stage Students in Saudi Arabia and its Relation to Some Social Associations. The 13th Conference for the Educational Work Leaders, Al-Baha, Saudi Arabia

Al-Zubair, A. (1999). The Concept of Citizenship Between the National \& the Global in the Speech of Islamic Movement in Algeria. A published research, The Centre of Arab Researches, The Arab Society for Sociology, Madbouli Library, Egypt.

Al-Zyood, K., \& Aranki, R. (2003). The students'Affairs: a New Though for a New Generation. The Conference of Students' Deanships, Zarqa Private University, Jordan.

Barnes, R., Auburn, T., \& Lee, S. (2004). Citizenship in practice. British Journal of Social Psychology, 43, 187-206. http://dx.doi.org/10.1348/0144666041501705

Busnaineh, A. (2006). The Horizons of Developing the Civil Education in The Arab Educational System in the book "Studies \& Researches of the Arab Meeting for Education and Sustainable Development in the Arab World". Beirut, Lebanon.

Chughtai, A. A. (2008). Impact of job involvement on in-role job performance and organizational citizenship behavior. Institute of Behavioral and Applied Management, Dublin City University, Ireland.

Gallup, G. (1977). Citizenship test for secondary schools. In Dan forth Foundation, and Charles F. Kettering Foundation, Education for responsible citizenship, Mc Graw Book Company, New York.

Hahn, C. (1999). Citizenship education: An empirical study of policy, practices and outcomes. Oxford of Education, 25, 231-250. http://dx.doi.org/10.1080/030549899104233

Khalid, M. (2001). Social Education \& Raising. Al-Naba' Magazine, 55. Sana'a, Yemen.

Khalil, A. K., \& Al-Kabsi, M. A. (2001). The Future of the Relation between the Educated \& the Authority. Dar Al-Fikr, Damascus, Syria

Lee, R. M., \& Robbins, B. (1995). Measuring the Social Connectedness, and Social Assurance Scales. Journal Counseling Psychology, 42(2), 232-241. http://dx.doi.org/10.1037/0022-0167.42.2.232

Mahaftheh, S. (2001). The Test of Citizenship for the 2nd Secondary Literary Stage Students in Jordan. The Periodical of the College of Education, 17th year, 17th issue, College of Education, Qatar University.

Mersho, G. M., \& Al-Huseiny, S. M. S. (2001). We \& the Other. Dar Al-Fikr, Damascus, Syria.

Nassar, N. (2000). In Political Education. Dar Al-Talee'a for Printing \& Publishing, Beirut, Lebanon.

Nasser, I. (2006). Citizenship. Al-Ra'ed Library, Amman, Jordan.

Sheehan Newspaper. (2008). Deterioration of the American's Cognitive Level. Amman, Jordan.

Woyach, R. B. (1992). Leadership in Civic Education. ERIC Digest.

Yafang, T. (2008). The relationship among job satisfaction, organizational citizenship behavior and turnover intention. Northeast Decision Sciences Institute Proceedings, March 28-30, 2008, Chung-Shan Medical University, Taiwan. 
Yaseen, A. (1998). In the Concept of Globalization. The Researches \& Discussions of the Intellectual Seminar organized by the Centre of Arab Unity, Beirut, Lebanon.

\section{Copyrights}

Copyright for this article is retained by the author(s), with first publication rights granted to the journal.

This is an open-access article distributed under the terms and conditions of the Creative Commons Attribution license (http://creativecommons.org/licenses/by/3.0/). 